\title{
乳幼児における身長一体重相対発育
}

\author{
森下はるみ \\ （昭和43年10月 7 日受付）
}

\section{A Study on Relative Growth of Weight and Height in Infants.}

\author{
Harumi Morishita: Risho Women's University.
}

\begin{abstract}
Longitudinal growth data of every month from birth to age 6 in 41 infants were examined.
\end{abstract} Weight $(Y)$ corresponding to height $(X)$ was plotted on logarithmic graph to obtain the allometric expression $\mathrm{Y}=\mathrm{bX} \cdot$, where $a$ is a growth index and $b$ is a constant.

The plotting showed a straight line and the first break of line (critical point) appeared at $5.1 \pm$ 1.4 month. After the critical point, the growth index a was decreased from $3.17 \pm 0.80$ to $1.57 \pm$ 0.25 . In most cases the critical point corresponded with the development of motor ability such as twisting their upper parts of the body when rolling over and sitting held their hands by adult. At the time when the critical point appeared, the tooth did not erupt yet, but the weaning was beginning to practise.

After the first critical point, two ( 12 cases) or three ( 9 cases) breaks of the line, in some, cases were observed. and the growth line appeared to be like a stair-case. But in these cases, any paticular factors such as enviromental or developmental changes which were considerd to be due to the critical points were not appeared. So it was simply considerd as the growth rhythm which was caused by the acceleration of weight growth alternated with that of the height.

\section{I .}

ヒトの発育期を区分する試みは，いままでに る，何人かの研究者によつてなされている，そ の指標としては，教育制度的なもの，精神一心 理的発連や身体の生理的変化にもとつくもの， 体型の変化にもとつくるのなど，さまさまであ る. 体型の変化を指標としたものの代表として は, 1922 年 Stratz ${ }^{8)}$ のいわゆる充実期, 伸長 期による区分がある.

この体型やプロポーションの変化を, 相対発

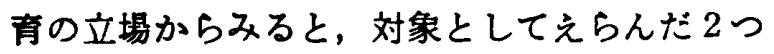
の形哲 $\mathrm{X} と \mathrm{Y}$ の間に allometry 式 $\mathrm{Y}=\mathrm{bX}$ が成立する時は，発育係数 $\mathrm{a}$ の值が変わること により把暒できる。これは四示すれば，両対数

立正女子大学
グラフルプロットされた発育曲楾（直線）の折 れ “変移点”としてあらわされる.1943年清水 7)は乳幼児の身長一体重相対発育について横断 的方法で研究し，その結果，乳幼児期には 2 個 の変移点が存在し，したがつて発育期は 3 段陼 に区分できること，発育段階がす寸むにつれ， 発青係数、は減少することを報告している． 1960年，著者"は，6〜18才の青少年について， 個々の身長一体重相対発育をるとめ，この期に は 2〜3 の発育段階に区分できること，発育段 階がすすむにしたがつて発育係数が増加するこ と，思春期にみられる変移点と初潮とに関連が ふかいことを明らかにした。本論では，さら に，0才から6才までの乳幼児について，個々 の身長一体重相対発育をるとめ発育曲線の型お よび発有係数の変異, 変移点と他の発達年令と 
の関連をるとめたので報告する。

\section{II . 対重およひ方法}

1961〜64年のあいたにに，東京都内に出生した 乳児で，出生児体重が $2500 \sim 3500 \mathrm{~g}$ ，出生啳

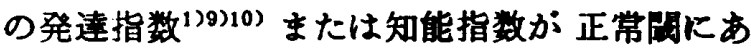
るもの41例について，各月ことの身長拈よび体 重值をるとめた。計测括よび発達の記録は，公 立保育園の保母，乳幼児施設の看㳟䀦，母親拈 よび著者による。

\section{III. 䟩 果}

対象とした 41 例中， 40 例に共通した变移点 は，身長 $63.6 \pm 4.0 \mathrm{~cm}$ にみられる。 これを第 I 変移点とよら, 平均体重括よび平均月令は,

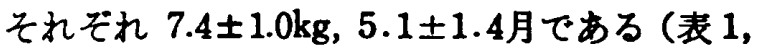
図 1 抢よび 2 参腒)。この点をさかいに，体重 発有係数の平均做は，3.17から1.57亿娍少する （表 1). 第 I 変移点以前についてみると，0月 から1月の体重発育係数がそれ以後より元進す

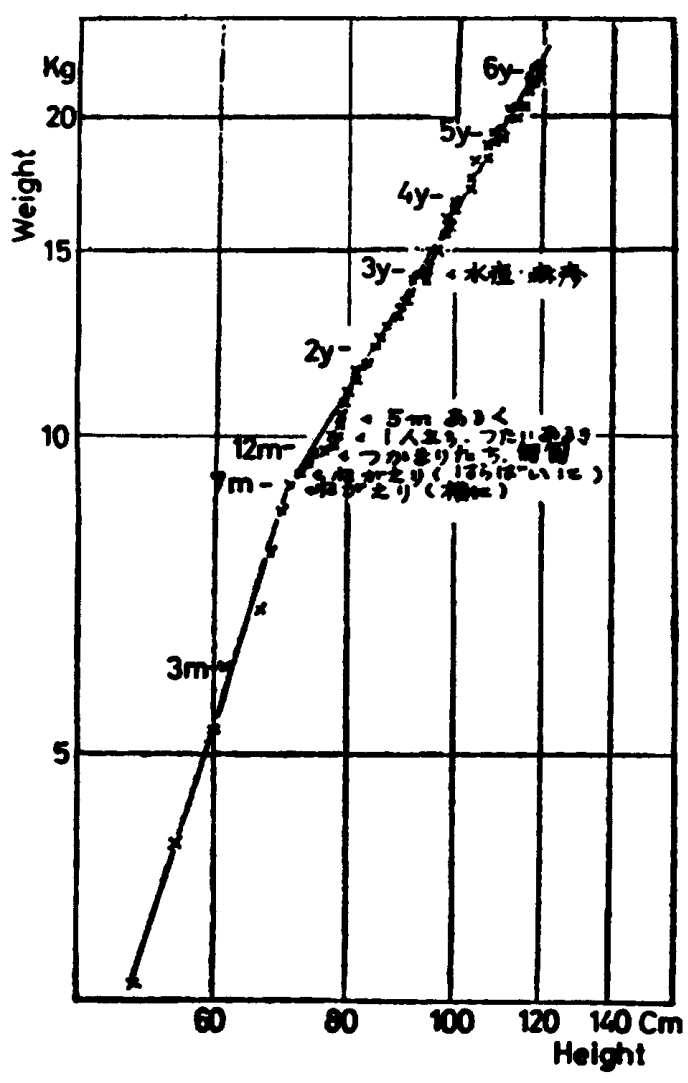

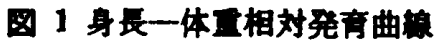

T. H.（男）出生时体亚 $50 \mathrm{~g} \varepsilon 2$

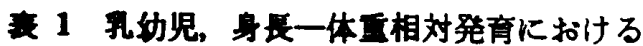
变移点および発育係数

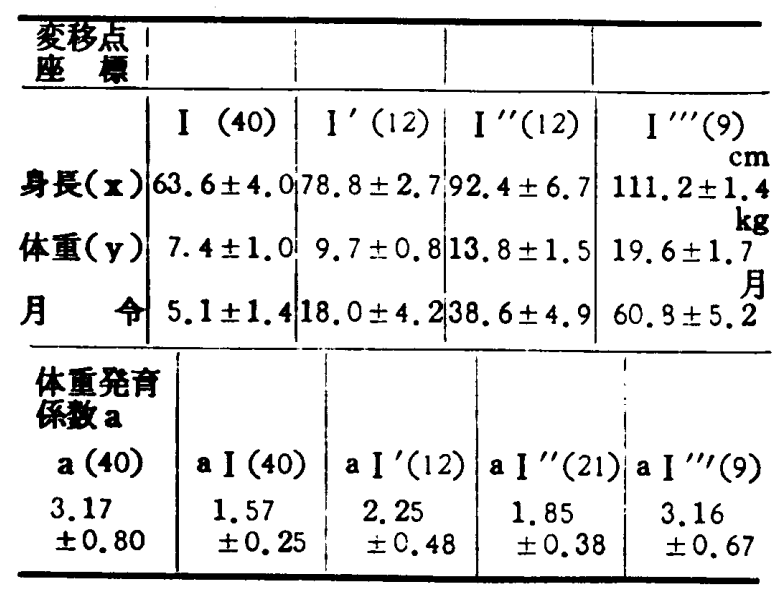

流（）は甽数をしめす。

ろ例は，8例にみられる。これらは，出生時体 重が 2500〜2800g にあり，少ない方にかたよ つている.

第I変移点以後についてみると，28例は変移 点がなく，汪ぼそのままで幼児期にいたる（図 1).のこりの12例は，体重発育係数 $\mathrm{a}$ が第 I 変 移点以後に娍少し，ついで增加さらに娍少をく りかえし，その結果，第 I 変移点以後，さらに 2 個の変移点がみられるるので，他の 9 例は 3 個の变移点がみられる（図2）。これらの変移点 I', I", I "“の平均身長, 平均体重, 平均月 令括よび標準偏差は表 1 の通りである。体重発 育係数 a b， 3.17(a), 1.57(a I ), 2.52(a I' ), 1.85 (a I ") , 3.16 (a I "') と増诚する（表 1).

\section{IV. 若}

41例中，40例保共通してみられる第I変移点 の存在と，その点を境にして体重発育係数が低 下する現象は，正常児に普边的なるのとみなし てよいのではなかららか？ 清水》が横断的方 法によつて得た結果は身長 $60.1 \mathrm{~cm}$, 月令 $4 \sim 5$ 月に第一变移点があり，発育係数、は男子で 3.16から1.89に，女子で2.90から1.93に娍少す ろ. また，昭和35年の厚生省值”をるとに，著 者が各月の身長，体臬平均值からるとめた結果 b，4〜5月に变移点がみられ，発骨係数、は 男子で3.23から1.54K，女子では3.25から1.79 に変る（図3）。これら清水，厚生省値からえた 


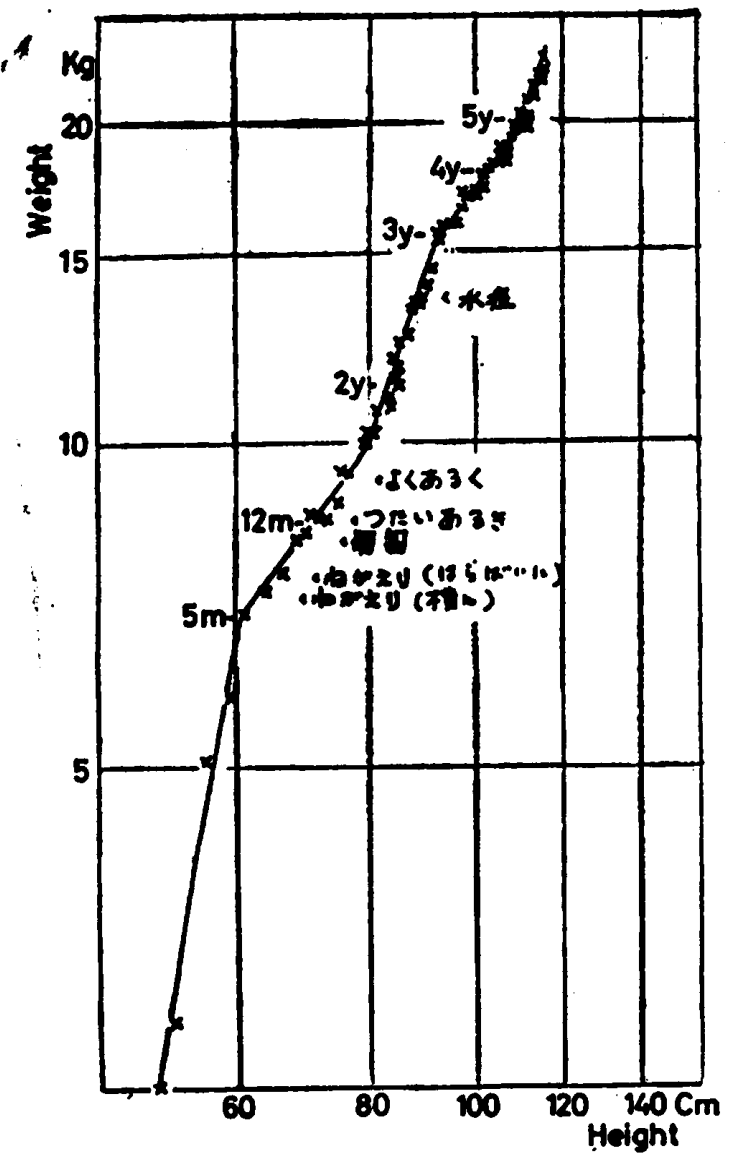

图 2 身長一体亚相対発育曲線

T. A. （女）出生時体重 $2500 \mathrm{~g}$

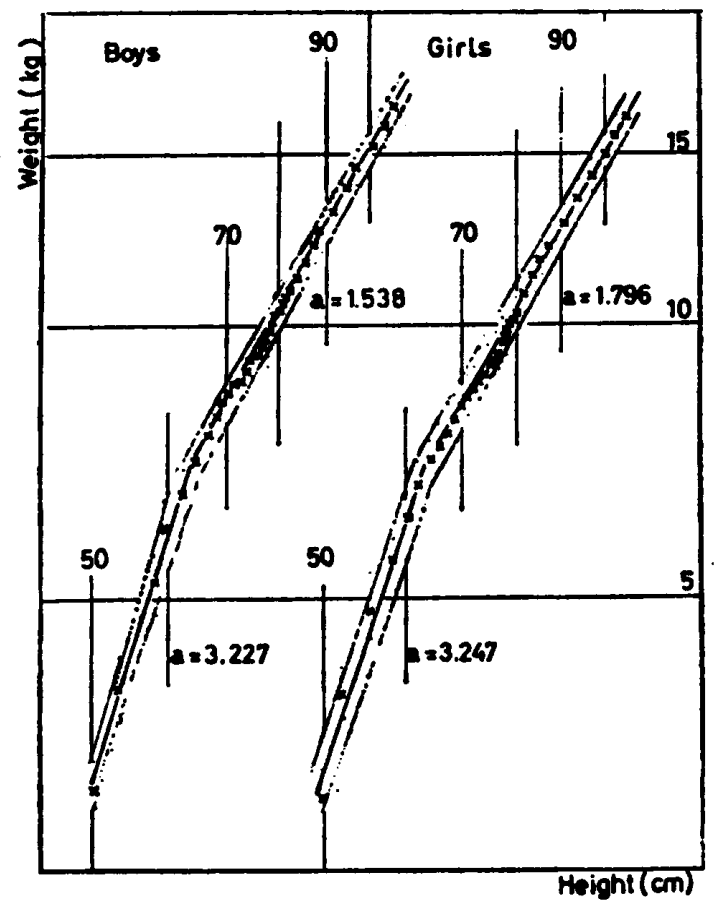

图 3 身長一体重相対発育曲站 35年, 厚生省值より作図
平均発青の結果と，本諭の個人発育の平均值と は，第 I 変移点については，よく一致するとい える。

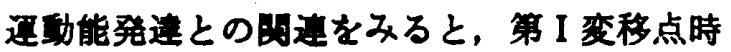
までに，不明の4例をのぞき，“肢ばいで，頭 と局を床からはなす”あるいは“腕で上体をさ

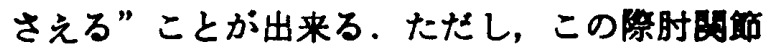
が伸びたまま，上体をおこしらろか否かは明礁 でない.

変移点（第 I）と前後してみられる能力は， “あ怙むけから横にれがえりする”こと，“両手 をあつてるらいすかる”ことである，その後の 置功発遮についてみると，“あをむきからはら ばいにねがえる”ことが出来るのは変移点時よ り $1 \sim 3$ か月後，さらに“つかまり立ち”“2・ 3 歩つたい歩き”が $3 \sim 5$ か月後にみられる。 以上のことから，第I変移点頃より，乳児の全 身的な活的性が增加してゆくことがかかる。

栄意との関連をみると，教乳金の添加例が 4 か月頃から多くなり，5か月以後には，全員に およら。たたし，その回数，目などは本㛝料か らは十分知ることがでさからた．第I变移点

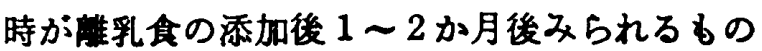
26例ですつとも多く，最大で 4 か力月後に变移点 がみられた。

疾病と第 I 変移点との関連についてみると， 4 か月頃より，2 年頃まで，るつとるしばしば みられるのは，咽頭炎，気管支炎などの呼吸器 系疾患と，それについで消化不良，下㢉などの 消化器系疾患である。しかし，疾病の程度や期 間については，個人差が大きく $1 / 3$ 以上の対象 児には疾病の記録はない，又，10人はどの対象 児には，同じような症状がくりかえしあらわ れ，なかには一年近く，つつくものもあつた. しかし，正常な小児と病気がちの小児の間に， 第I 変移点後の 発育係数の值に差はみられな w.

齿牙発育と第I変移点との関連をみると，第 I 変移点時は乳菊の発生が上/下䫑とも0/0で, 1 〜 2 か月徭に0/2になる例が27例でるつとる 多い，0/1のbのは 2 例，一番榑牙発育のすす んだ例は，変移点時 $4 / 2$ であつた。たたしこ 
の事例は，変移点が 8 か月頃にあり，平均を比 ベやや括てい。

以上，通動能，栄菨，疾病，齿牙発青と第 I 変移点との関連をみた．第 I 変移点のはじまる 5 か月前後は，運功能の発速に上る活娌エネル ギーの増加, 檼，それらにとるなら小児の内 的, 外的生活状況の変化が大きく影整している 時期といえる。

アメリカで小児の発育評価に広くもちいられ ているWetzel Grid"1) は，身長一体重の対数 值をるとに，この直線性を利用している点で一 種の allometry にもとつく評価法ともいえる。 しかし，日本の小児にこの Grid による評価を 利用する際は，すくなくとも，第 I 変移点を考 㦄に入れるなら，生後 5 か月頃を境に，2つの 異なる傾斜をるつ Grid をるちいるのが妥当で はなかろらか？

条 I 変移点後, 2 ないし 3 の変移点（I', I"，I“"）をしめす 12例については，とくに

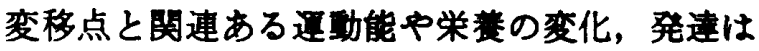
明らかでない，疾病については，1〜6才のあ いたにに，約半数が水廈，疼の両方か片方にか かつている，その際，体重発育か： 2 3 か月停 滞し，図にプロットした点が重なる例が多い。 やや長期にわたつて，体重発育係数が变化した 例は、このほか 2 例であった。 そのらちの1つ は，生後25か月から4か月わたつて水㢄，麻 疹，中耳炎を続発し，病後を含む 9 か月間，体 重発育が停㴋した男子（Y.H.）である。これに よれば，生後24か月目の体重 $11.5 \mathrm{~kg}$ ，身長88.4 $\mathrm{cm}$ は32か月目には体重 $11.8 \mathrm{~kg}$, 身辰 $96.3 \mathrm{~cm}$ 33 か月目に体重 $12.9 \mathrm{~kg}$ ，身長 $96.3 \mathrm{~cm}$ となる。 その間の体育発育係数aは 0.409 と低下し， 33 か月以後 2.541 に回復する. 他の 1 例はやはり 男子（K.S.）で，28か月目から32か月目まで赤

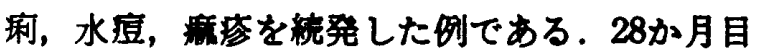
の体重は $12.4 \mathrm{~kg}$, 身長 $84.7 \mathrm{~cm} 36$ か月目の体 重 $13.1 \mathrm{~kg}$, 体重 $91.2 \mathrm{~cm}$ で約 9 か月間，体重 発育係数 a は 0.755 と低下し，のち2.084に回得 するものである。（図 4)

この 2 例をのぞく上㴶の12例については変移 点時に，これと開連あると思われる特別の現象

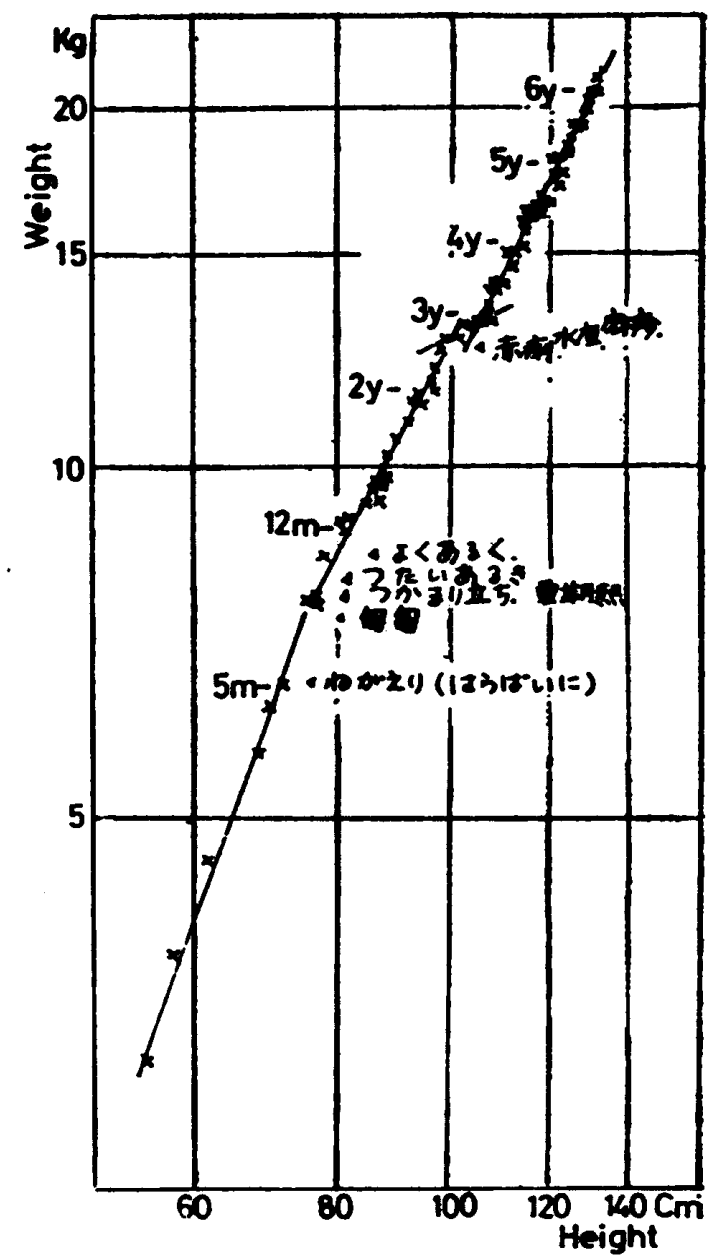

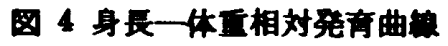

K. S.（男）出生時体面 $3150 \mathrm{~g}$

や子どるの日常生活上の变化がみられない，し たがつて，身長と体重の発青が交互に促進する 一種の発青リズムとみなしてよいのではなかろ 5か. なお，清水 ") か平均成長について辄告し ている 4 5才頃の第 II 变点については, 本算料では明らかに出来なかつた。

以上をまとめると，身長一体直相対発育の立 場からみて，乳幼児期は 5 か月頃を境に，はほ 2つの 発育段陼に区分できる，なを学令期につ いては，ナでに邦告”したように思春期にみら れる変移点と 7〜9才頃に29\%のるのにみられ る変移点とがある．そこで，乳児期から青年期 までの発育過程は，4ないし5 の発育段腈に区 分でき，それそれの变移点は 5 か月，6才，14 才（女子は12才）頃にみられ，1 部分は 8 才頃 にる変移点がみられる。 


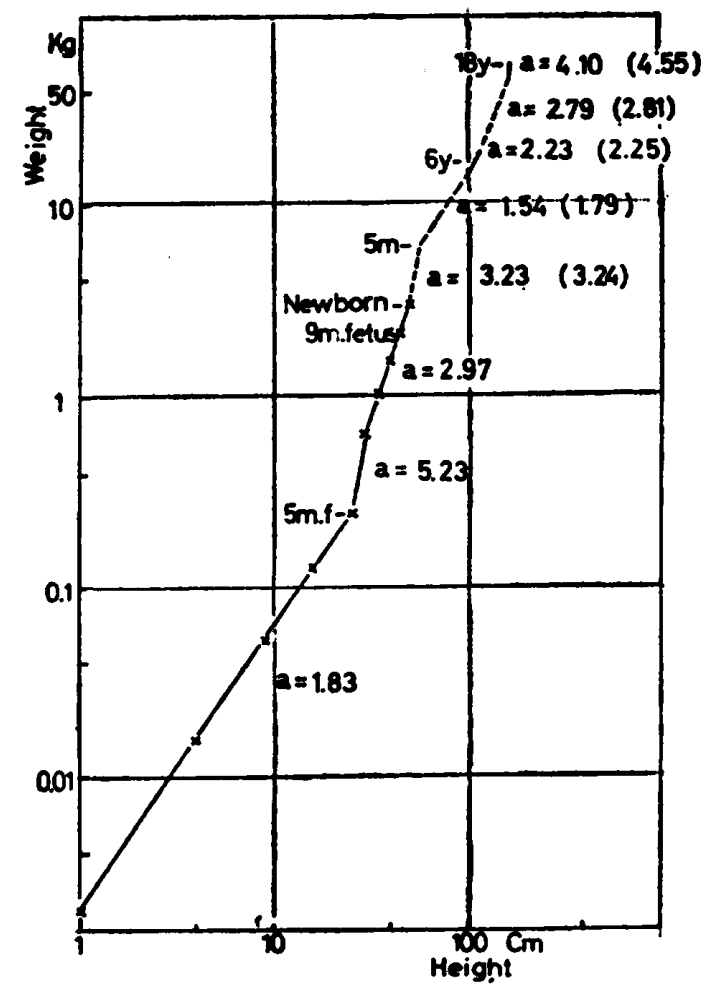

図 5 ヒトの身長一体重相奶発育曲線および 発育係数，（）は女子。

胎 览 期: Haase (身長)，体重）推定值より 秏幼児期：35年 厚生省值より

育少年期：35年 文部省值より作図.

この発育区分を平均発育についてみてみた。 胎坚期は身長を Haase, ${ }^{2)}$ 体重を林中)の各月こ との推定值, 乳児期3) は35年厚生省值, 青少年 期は $35^{5)}$ 年文部省值について，年令別，身長， 体重平均值から発育曲線をえた（四 5)。胎児 期はこれによると 5 か月前と 6 か月後に大きく 2 分でき，体重の発育係数 $\mathrm{a}$ は1.83から2.97 大きくなる．出生後発育については，発育曲線 の型，変移点坐標括よび年令は，本論の結果と 注济する．ただし，学令期以後の体重発育 係数 $\mathrm{a}^{4)}$ は，6才 8 才では個人発育の平均が男 子 1.46 , 女子 1.50 と文部省值よりすくなく，逆 に, 思春期後については, 男子5.76, 女子 5.50 と多い。

\section{V. 括}

東京都内に 1961 年以後出生した勫幼児 41 名 について，個ヶの身長一体重相対発育をるとめ
た. 生後1か月から6才までの発育期を通し， 生後5.5か月頃を境比身長一体直相対発育は2つ の発育段階に区分でき，体重発育保数 a の平均 は3.17から1.57に娍少する。この変移点時は， 乳児のねがえりや坐位能力の始まりと一致し， したがつて，全身的活功力の增す時点といえ る.一方，噰乳期とも一致している．この時点 に拈ける歯牙発生は，大部分0であつた。

5 か月以後の 変移点についてみると，2つ (12例) または3つ（9例）の変移点がみられる 事例むある。そして，これらの副次的な変移点 を境に，身長一体重発育係数 a は增加と娍少を くりかえし，発育曲線は倩段状に上昇する。こ れら副次的な変移点 I'，I"，I“'と運動能, 栄養, 疾病などの関連は明確ではない。また。 子どすの日常生活に異常や変化がみられないこ とから，身長と体重発育が相互に促進する一種 の発育りズムともみなしらる。

学令期以後について，すでに報告した結果と あわせると，身長一体重相対発育とい5立場か らみれば，乳幼児期では 2 , 学令期では 2 また は3 の発育段陼に区分でき，全体を通じて 4 か ら5の段階に区分できる。

本研究を御指透・御校的下さいました，東京大学 教授，猪蚼逆夫先生に深く感謝いたします。

\section{女 触}

1) Gesel, A. and Amatruda, C.S. (1941): 质 䢖新断学, 新井・佐野訳 (1958)，日本小児医 亟出版社.

2) Hasse: Chariteannalen, Bd. 2, S, 686; Lehrbuch der Geburtshilfe, W. Stoeckel, VEB. GUSTAV FISHER VERLAG JENA （1956）上り引用.

3）船川・林・的石 (1963)：昭 35 年度わが国の

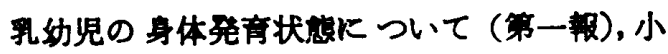
児保健研究，21 (1)

4）森下 (1965)：相対発奇よりみた成热の研究 体育学研究，8，3-4.

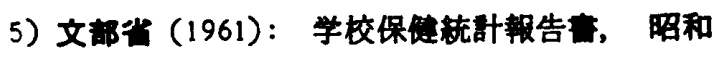
35年度, 文部省.

6）样：科举，長谷川（1949），南山堂上り引 
用.

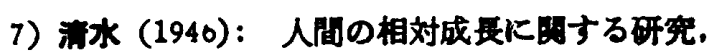
北降往.

8）Stratz, C. H.：子供のからた，森体治积 (1952), 㓣文社.

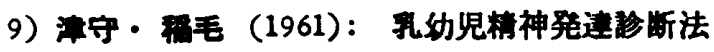

大日本国责。

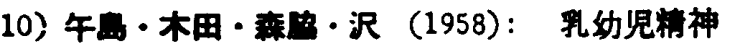

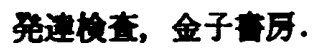

11) Wetzel, N.C.(1946): An Application of the Grid Technique to Growth and Development in Infants, J. of Pediatrics, 29. 